\title{
MEASUREMENT OF SERUM BIOCHEMICAL LIVER PARAMETERS AND HCV RNA LEVELS FOR DETECTION THE SEVERITY OF HEPATITIS C VIRUS-ASSOCIATED HEPATOCELLULAR CARCINOMA
}

Mohamed E. Ebeid', Ibrahim H. El Sayed ${ }^{2}$, Ismail I. Hegzy3, Maha A. F. El Mansy ${ }^{4}$, Samah Mamdouh ${ }^{5}$, Fatma khorshed ${ }^{5}$, and Maysa Ramzy Najib Abd Rabou ${ }^{6}$

${ }^{1}$ Biochemistry and Molecular biology Department, Genetic Engineering and Biotechnology Research Institute, Sadat City University, Egypt.

${ }^{2}$ Biochemistry, Faculty of Science, Kafr El-Sheikh University, Egypt.

${ }^{3}$ Biochemistry Department, Faculty of Medicine, Al-Azhar University, Egypt.

${ }^{4}$ Clinical and Chemical Pathology, Haematology Department, Theodor Bilharz Research Institute, Egypt.

${ }^{5}$ Biochemistry and molecular biology, Theodor Bilharz Research Institute, Egypt.

${ }^{6}$ Medical Laboratories, Faculty of Applied Medical Sciences, October 6

University, Egypt.

\section{ABSTRACT}

Hepatitis $C$ virus $(\mathrm{HCV})$ is one of the leading causes of chronic liver disease. Hepatocellular carcinoma (HCC) is a major complication associated with HCV virus infection, with significant mortality and morbidity rates. This study aimed to measure biochemical liver parameters and HCV RNA levels for detection the severity of hepatitis $C$ virus- associated hepatocellular carcinoma.

The study was conducted on 100 patients, with ages ranging from 36 to 68 years and patients grouped into four groups. The 1 st group served as control group $(n=25)$, the second group $(\boldsymbol{n}=\mathbf{2 5})$ : Hepatitis C Virus, the third group $(\boldsymbol{n}=25)$ : $H C V$-associated HCC and the fourth group $(\boldsymbol{n}=25)$ : After HCC removal and tumor resection. Serum samples were collected from the studied patients. Liver function enzymes (ALT, AST, Alkaline phosphatase) and another function parameters (Albumin and Total bilirubin) were tested to all patients of the studied groups.

The results showed that hepatitis $C$ Virus, $H C V$-associated HCC, and after HCC removal groups had an increase in liver function enzymes, decrease in albumin levels, and an increase in total bilirubin levels which indicate damage in the liver. Viral loads indicated in males infected higher than in females and significantly 
increased in $\mathrm{HCV}$ patients, and a highly significant increase in $\mathrm{HCV}$ associated HCC patients.

Conclusively, Hepatitis C Virus, HCV-associated HCC, and After HCC removal groups had an increase in liver function enzymes, decrease in albumin levels, and an increase in total bilirubin levels which indicate damage in the liver. Viral loads indicated in males infected higher than females are significantly increased in HCV patients, and a highly significant increase in $\mathrm{HCV}$ associated HCC patients.

Keywords: Liver parameters; HCV; hepatocellular carcinoma; HCC.

\section{INTRODUCTION}

Hepatocellular carcinoma (HCC) is the fifth most common cancer and the second leading cause of cancer mortality worldwide. More than 700000 new cases are diagnosed every year throughout the world (Ferlay, et al. (2014). In Egypt, HCC was reported to account for about $4.7 \%$ of chronic liver disease (CLD) patients ( Bray et al. , 2018).

The geographical variation in the incidence of HCC is mostly related to the different prevalence of major risk factors for $\mathrm{HCC}$, such as hepatitis $\mathrm{C}$ virus (HCV) and hepatitis B virus (HBV) infection (Gupta et al.,2017).

In developed countries, the epidemic of obesity, diabetes and nonalcoholic steatohepatitis (NASH) is also believed to contribute to the observed increase in HCC incidence (Bartosch et al., 2009). However, the overriding risk factor for HCC, which is responsible for HCC in 80-90 \% of cases regardless of etiology, is the presence of cirrhosis (Yapali and Tozun , 2018).

$\mathrm{HBV}$ and $\mathrm{HCV}$ infection are considered as the major risk factors that contribute to the development of HCC. This is evidenced by several studies that analyzed the risk factors of HCC in patients with CLD. Previously, there was strong evidence that hepatitis B virus (HBV) was the major cause of HCC in Egypt, but more recently HCV has become the predominant factor associated with the more recent increased incidence of HCC (Abdelmoez et al. ,2019).

$\mathrm{HCV}$ is an RNA virus with a purely cytoplasmic life cycle, unlike the hepatitis B virus, which directly integrates into the genetic material of the cell. HCV-associated hepatocarcinogenesis is thought to be multifactorial, arising from direct viral oncogenic effects as well as from 
mutagenic insults to the hepatocyte genome accumulated from rounds of inflammation and fibrosis associated with a chronic viral infection. HCV infection itself is associated with a 15-20 fold increased risk of HCC development ( $\mathrm{Li}$ and Chung, 2015).

Treatment of $\mathrm{HCV}$ has dramatically advanced in the past 5 years. The new direct acting antiviral agents (DAAs) yield outstanding results with $>90 \%$ of patients with HCV achieving sustained virologic response (SVR) after 12 weeks of treatment (Gupta et al.,2017).

Therefore, this study aimed to assess biochemical liver parameters and HCV RNA levels for detection of the severity of hepatitis C virusassociated hepatocellular carcinoma.

\section{PATIENTS AND METHODS}

This study was conducted on 100 patients, with ages ranging from 36 to 68 years, and grouped into healthy patients (control), hepatitis C Virus, HCV-associated HCC, and after tumor resection groups, showed in Table 1. At enrollment, patients completed a questionnaire on their medical history and HCC risk factor.

The use of abdominal ultrasound for early detection of hepatocellular carcinoma (HCC) in patients with chronic viral hepatitis $\mathrm{C}$ virus infection.

Exclusion criteria: Infected patients with immunodeficiency virus (HIV), autoimmune hepatitis or HBV were excluded from this study. This study was approved by the ethics committee of Theodor Bilharz Institute. The written informed consent was obtained from each participant according to the institutional guidelines.

Table (1): Types and number of patient's groups

\begin{tabular}{|l|c|c|c|c|}
\hline Group & $\begin{array}{c}\text { Control } \\
\text { (Healthy } \\
\text { Patients }\end{array}$ & $\begin{array}{c}\text { Hepatitis C } \\
\text { Virus } \\
\text { (HCV) }\end{array}$ & $\begin{array}{c}\text { HCV } \\
\text { associated } \\
\text { HCC }\end{array}$ & $\begin{array}{c}\text { After } \\
\text { tumor } \\
\text { Resection }\end{array}$ \\
\hline Number (n) & 25 & 25 & 25 & 25 \\
\hline
\end{tabular}

\section{Serum collection:}

Five $\mathrm{ml}$ of blood samples were obtained from 75 patients and 25 healthy control by venous puncture, allowed to be clotted for 30 minutes and centrifuged at 2500_rpm for 10 minutes to get the serum sample for biochemical parameters including Alanine amino transferase (ALT); 
Aaspartate amino transferase (AST); albumin( ALB); Total bilirubin (T. Bili), Alkaline phosphatase (Alk.ph.).

The serum was then collected and allocated into new tubes Supernatant was thrown away, and the pellet was stored at $\left(-80^{\circ} \mathrm{C}\right)$ until use for molecular parameters. Collection and manipulation of the samples were under following relevant approved guidelines.

\section{Quantification of HCV (RNA) in human serum:}

$\mathrm{HCV}(\mathrm{RNA})$ is quantified by using the Abbott Real Time HCV kit for the quantitation of hepatitis $\mathrm{C}$ viral (HCV) RNA in human serum from $\mathrm{HCV}$-infected individuals. Specimens containing HCV genotypes $1-6$ have been validated for quantitation in the Assay (Des Plaines, IL 60018 USA, 2011).

\section{Statistical analysis}

Analysis of The data were analyzed by SPSS statistical software (IBM SPSS: Version 25. Inc., Chicago, IL, USA) (SPSS, 2020). Data are presented as a mean \pm standard deviation $( \pm \mathrm{SD})$. Comparisons of quantitative variables were performed between groups by using Duncan $\mathrm{s}$ New Multiple Range test, (Duncan, 1955). In all cases, a $P$-value was considered indicative of significance if it was equal to or less than 0.05 ( $P$ $\leq 0.05)$.

\section{RESULTS}

ALT and AST are highly significant increased $(\mathrm{P}<0.001)$ in patients infected with $\mathrm{HCV}$ and $\mathrm{HCV}$ associated $\mathrm{HCC}$, also after tumor resection group are higher expressed in comparison with control patients. Lower significant $(\mathrm{P}<0.001)$ concentration of albumin levels illustrated in patients with $\mathrm{HCV}, \mathrm{HCV}$ associated $\mathrm{HCC}$, and after tumor resection in comparison with control patients. Highly significant levels $(\mathrm{P}<0.001)$ of total bilirubin are shown, markedly increased in $\mathrm{HCV}$ patients and significantly $(\mathrm{P}<05)$ increased in $\mathrm{HCV}$-associated $\mathrm{HCC}$, and after tumor (HCC) resection group.

Results show highly significant levels $(\mathrm{P}<0.001)$ of alkaline phosphatase markedly increased in the $\mathrm{HCV}$ patients, $\mathrm{HCV}$-associated HCC, and after tumor (HCC) resection patients compared to the lower level of control patients (Table 2).

Viral loads are significantly increased in HCV patients $(\mathrm{P}<0.05)$, and highly significant increased in HCV associated HCC patients with $\mathrm{P}<0.001$ ( Tables 3, 4 and Figure 1). 
101

Table (2): Serum levels of liver function enzymes of (ALT, AST, and Alkaline phosphatase) and liver function parameters of Albumin, and Total bilirubin.

\begin{tabular}{|c|c|c|c|c|c|}
\hline Parameters & $\begin{array}{c}\text { Control } \\
(n=25)\end{array}$ & $\begin{array}{c}\text { HCV } \\
\text { Patients } \\
(n=25)\end{array}$ & $\begin{array}{c}\text { HCV } \\
\text { Associated } \\
\text { HCC } \\
\text { Patients } \\
(n=25)\end{array}$ & $\begin{array}{c}\text { After } \\
\text { HCC } \\
\text { resection } \\
\text { Patients } \\
(n=25)\end{array}$ & Significance \\
\hline ALT & $\begin{array}{c}18.43 b \pm \\
3.26\end{array}$ & $\begin{array}{l}67.6 \mathrm{a} \\
\pm 24.4 \\
\end{array}$ & $\begin{array}{l}55.8 \mathrm{a} \\
\pm 19.4\end{array}$ & $\begin{array}{c}63.5 \mathrm{a} \pm \\
10.6\end{array}$ & $* *$ \\
\hline AST & $\begin{array}{c}18.29 b \pm \\
4.57\end{array}$ & $\begin{array}{l}96.7 \mathrm{a} \\
\pm 19.3\end{array}$ & $\begin{array}{l}90.1 \mathrm{a} \\
\pm 23.8\end{array}$ & $\begin{array}{c}85.0 \mathrm{a} \pm \\
20.0\end{array}$ & $* *$ \\
\hline Albumin & $\begin{array}{c}4.77 a \pm \\
0.19\end{array}$ & $\begin{array}{l}2.93 \mathrm{~b} \\
\pm 1.21\end{array}$ & $\begin{array}{l}2.76 b \\
\pm 0.54\end{array}$ & $\begin{array}{c}3.0 \mathrm{~b} \pm \\
0.24\end{array}$ & $* *$ \\
\hline T. Bili & $\begin{array}{c}0.50 \mathrm{~b} \pm \\
0.17\end{array}$ & $\begin{array}{l}1.84 a \\
\pm 2.10 \\
\end{array}$ & $\begin{array}{c}1.16 \mathrm{a} \\
\pm 0.52\end{array}$ & $\begin{array}{c}1.20 \mathrm{a} \pm \\
0.39\end{array}$ & $* *$ \\
\hline Alk. Ph & $\begin{array}{c}63.29 b \pm \\
10.31\end{array}$ & $\begin{array}{c}165.42 \mathrm{a} \\
\pm 46.1\end{array}$ & $\begin{array}{c}175.0 \mathrm{a} \pm \\
49.9\end{array}$ & $\begin{array}{c}168.7 \mathrm{a} \pm \\
8.0\end{array}$ & $* *$ \\
\hline
\end{tabular}

ALT: Alanine amino transferase; AST: Aaspartate amino transferase; T. Bili: Total bilirubin, Alk. Ph: Alkaline phosphatase

Table (3): Frequencies of Viral load.

\begin{tabular}{|c|c|c|c|}
\hline \multirow{2}{*}{ Variables } & Description & $\mathbf{N}$ & $\boldsymbol{\%}$ \\
\hline \multirow{2}{*}{ Sex } & Male & 35 & 70.0 \\
\cline { 2 - 4 } & Female & 15 & 30.0 \\
\hline \multirow{2}{*}{ Group } & HCV & 25 & 50.0 \\
\cline { 2 - 4 } & HCV associated HCC & 25 & 50.0 \\
\hline
\end{tabular}

Table (4): Descriptive Statistics of Viral load groups.

\begin{tabular}{|l|c|c|c|}
\hline Variable of Viral load & N & Mean \pm SD & P-Value \\
\hline HCV & 25 & $329656.33 \pm 287756.93$ & $<0.05^{*}$ \\
\hline HCV associated HCC & 25 & $1947395.68 \pm 1489569.27$ & $<0.001^{* *}$ \\
\hline
\end{tabular}




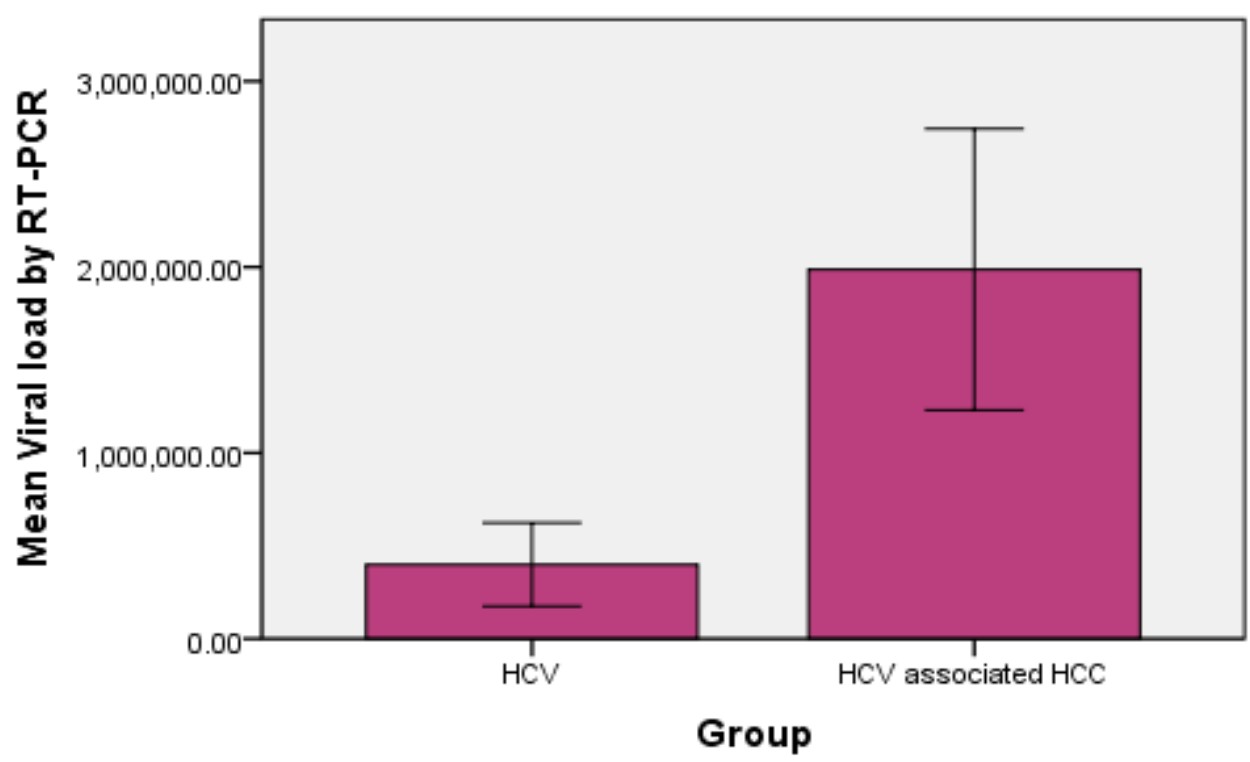

Figure1: Viral loads in HCV and HCV associated HCC group.

\section{DISCUSSION}

HCV-related carcinogenesis results from a complex combination of host, environmental and viral factors. The induction of hepatocarcinogenesis is assumed to be mainly triggered via the indirect effect of immune-mediated chronic inflammation. However, HCV may also directly induce HCC by altering several host regulatory pathways involved in proliferation, energy metabolism, angiogenesis, epithelialmesenchymal transition (EMT), DNA repair, apoptosis, and oxidative/endoplasmic reticulum (ER) stress ( Bartosch et al., 2009)).

In this study, serum activities of hepatic transaminases in all cases, ALT and AST were significantly increased compared to the control patients that reflected active hepatitis due to viral infection. The serum level of AST in the studied groups was higher by about 4.9 times than that in the control group, which is statistically significant $(\mathrm{P}<0.05)$, and these results are in agreement with Durazo et al., (2008) and Lopez et al., (1996) who found that the mean value of AST in HCC was 3.5 times than the upper limit of normal, and also with Okonkwo et al., (2011) who found that the serum AST in HCC was 1.39 times the upper limit of normal; the serum ALT level showed a statistically significant higher where the mean value in the HCV group was 3.7 times the upper limit of normal, 3.0 times 
103

and 3.4 the upper limit of normal in the (HCV associated HCC) group, and in the after tumor resection group, respectively which are in agreement with Durazo et al., (2008) and Lopez et al., (1996).

According to other liver function tests, serum albumin, and bilirubin, showed a highly significant difference between the studied groups, the bilirubin levels were higher by about $268 \%$ in the HCV group, $132 \%$ in the $\mathrm{HCV}$ associated HCC group ;and $140 \%$ in the HCC resection group compared to the control group. The albumin levels were lower by about $38.6 \% 42.1 \%$, and $37.1 \%$ respectively in HCV, HCV associated HCC, and $\mathrm{HCC}$ resection group compared to the control group, and these results are in agreement with Durazo et al., (2008) who stated as that HCC patients had higher levels of serum bilirubin $(\mathrm{P}=0.0059)$, international normalized ratio $(\mathrm{P}<0.0001)$, and lower albumin levels $(\mathrm{P}<0.0001)$ compared with non-HCC patients.

Okonkwo et al., (2011) also found that the average serum bilirubin value was four times than the upper limit of normal in the HCC patients. In liver cirrhosis, the average bilirubin was 2.8 times than the upper limit of normal, and $57.5 \%$ of the patients had elevated bilirubin levels. The average bilirubin level was normal in patients with chronic hepatitis.

Also, the activities of serum alkaline phosphatase increased in the studied groups by about $161.3 \%$ in the HCV group, $176.5 \%$ in the HCV associated HCC group , and $166.5 \%$ in the HCC resection group compared to the control group. Increased preoperative serum ALP levels and intrahepatic metastasis were predisposing factors for tumor recurrence after hepatectomy.

Conclusively, Hepatitis C Virus, HCV-associated HCC, and After HCC removal groups had an increase in liver function enzymes, decrease in albumin levels, and an increase in total bilirubin levels which indicate damage in the liver. Viral loads indicated in males infected higher than females are significantly increased in $\mathrm{HCV}$ patients, and a highly significant increase in $\mathrm{HCV}$ associated $\mathrm{HCC}$ patients.

\section{REFERENCES}

Abdelmoez FA, Imam HM, kamal Idriss N, Wahid LA, Abbas WA, Abozaid MAA, et al. (2019). The role of hepatitis $C$ virus and possible risk factors in development of hepatocellular carcinoma: 400 patients based study. Egypt Journal Intern Med. 2019;31(1):64.

Bartosch B, Thimme R, Blum HE, Zoulim F. (2009) Hepatitis C virusinduced hepatocarcinogenesis. Journal of Hepatol.;51(4):810-20. 
Bray F, Ferlay J, Soerjomataram I, Siegel RL, Torre LA, Jemal A. Global cancer statistics 2018: GLOBOCAN estimates of incidence and mortality worldwide for 36 cancers in 185 countries. CA Cancer Journal Clin. 2018;68(6):394-424.

Duncan, D.B. (1955). Multiple range and multiple F-test. Biometrics, 11: 1- 42.

Durazo FA, Blatt LM, Corey WG, Lin J, Han S, Saab S, et al. (2008).Des- $\gamma$-carboxyprothrombin, $\alpha$-fetoprotein and AFP-L3 in patients with chronic hepatitis, cirrhosis and hepatocellular carcinoma. Journal Gastroenterol Hepatol. 2008; 23(10):1541-8.

Ferlay, J.; Soerjomataram, I.and Ervik ,M.(2014): GLOBOCAN v1.0. Estimated cancer incidence, mortality, and prevalence worldwide. Available at http://globocan.iarc.fr.

Gupta V, Kumar A, Sharma P, Arora A. (2017). Newer direct-acting antivirals for hepatitis C virus infection: Perspectives for India. Indian Journal Med Res. 2017;146(1):23.

Li DK and Chung RT.(2015). Impact of hepatitis $C$ virus eradication on hepatocellular carcinogenesis. Cancer. 2015;121(17):2874-82.

Lopez JB, Balasegaram M, Thambyrajah V, Timor J. (1996). The value of liver function tests in hepatocellular carcinoma. Malays $J$ Pathol. 1996;18:95-100.

Okonkwo UC, Nwosu MN, Nnadozie OJ, Mamah V V, Nsoedo CW. (2011). Is liver function test of any diagnostic relevance in patients presenting with hepatocellular carcinoma? Orient Journal Med. 2011;23(1-4):17-23.

SPSS (2020). SPSS Users Guide Statistics. Version 8. Copyright SPSS lnc., USA.

Yapali S and Tozun N.( 2018). Epidemiology and viral risk factors for hepatocellular carcinoma in the Eastern Mediterranean countries. Hepatoma Res. 2018;4:24-34. 
105

قياس مستويات وظائف الكبد البيوكيميائية في الام و الحمض النئ النووي

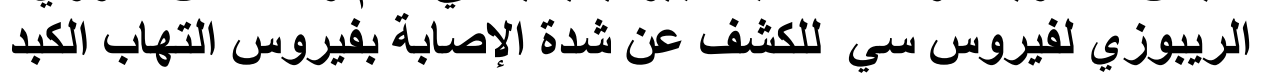
سي المرتبط بسرطان الخليه الكبايه

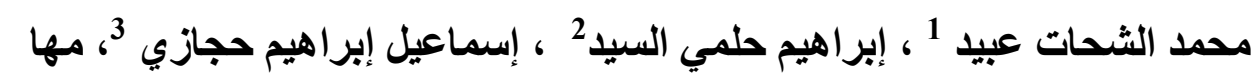

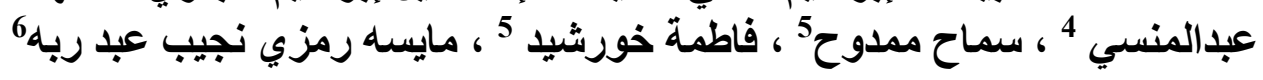

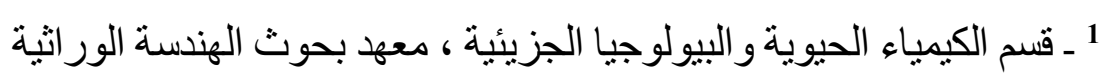

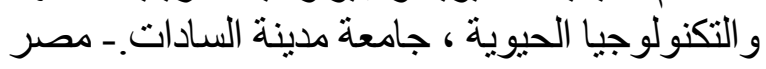

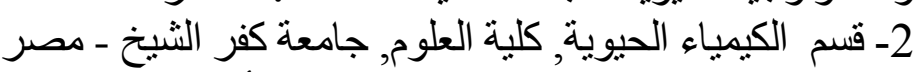

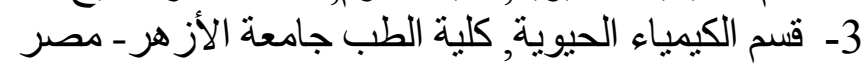

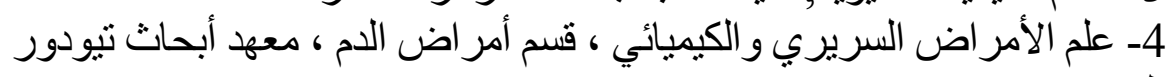

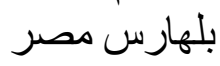
5- الكيمياء الحيوية و البيولوجيا الجزيئية ، معهد أبحاث تيودور بلهارس- مصر

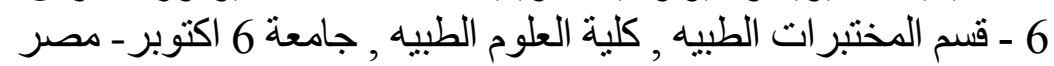

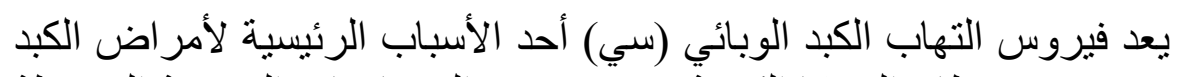

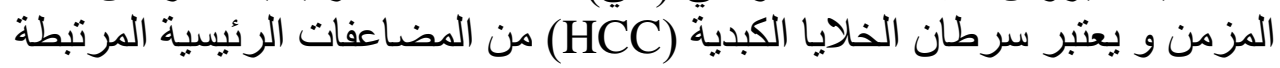

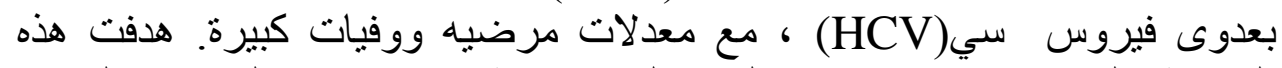

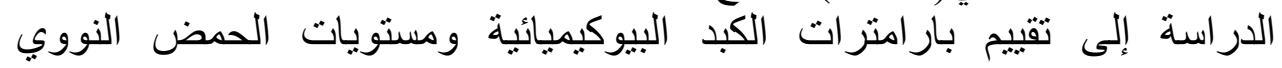

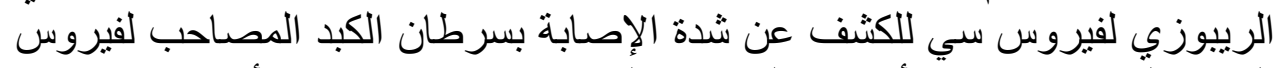

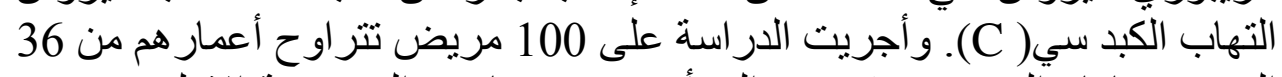

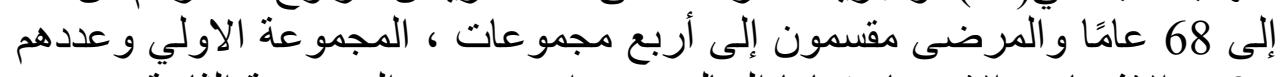

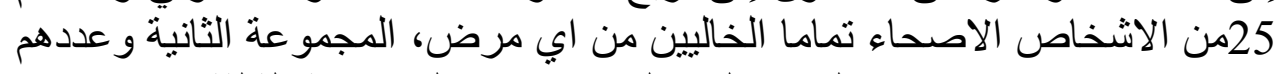

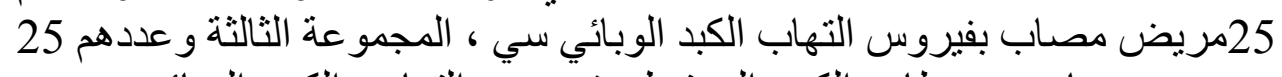

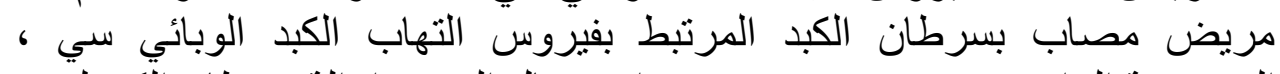

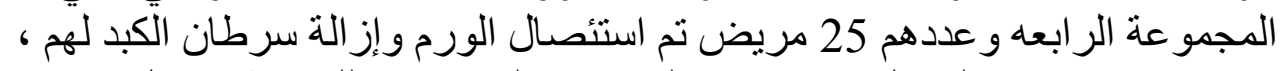

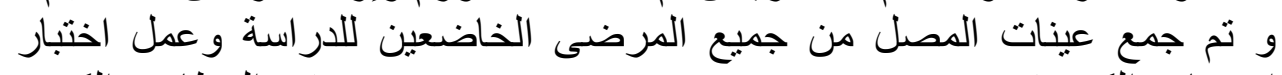

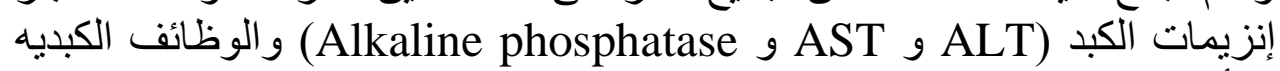
(الألبيومين و الصفر اء) لجميع المرضى الخاضعين للإر اسه

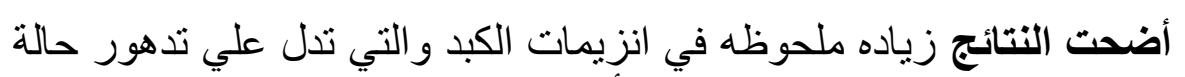

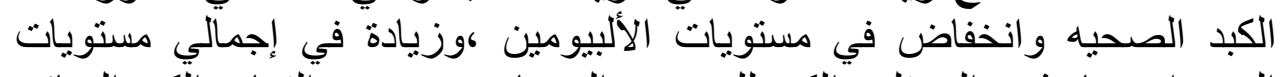
الصفر اء مما يشير إلى تلف الكبد للمرضي المصابين بفيروس ألتهاب الكبد الوبائي 
سي المرتبط بسرطان الخليه الكبديه و أظهرت النتائج أيضا أن الأحمال الفيروسية

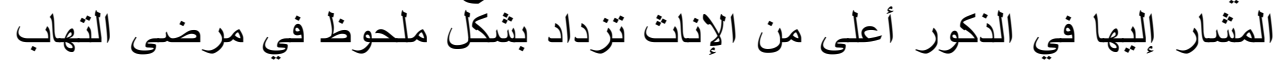

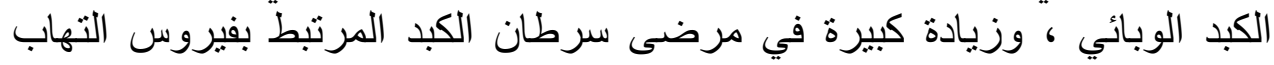

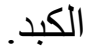

التوصية: من هذه النتائج كان لفيروس التهاب الكبد الوبائي C ، و بـ HCV ، و ومجمو عات ما بعد إز الة HCC زيادة في إنزيمات وظائف الكبد ،

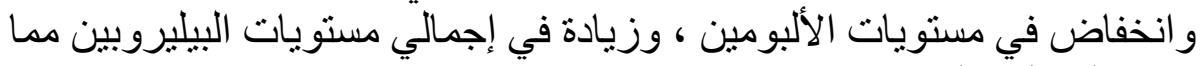
يشير إلى تلف الكبد.

الأحمال الفيروسية المشار إليها في الذكور أعلى من الإناث تزداد بشكل ملحوظ في مرضى التهاب الكبد الفيروسي ، وزيادة ملحوظة في مرضي لإنى سرطان الكبد المرتبط بفيروس التهاب الكبد. 